\title{
4
}

\section{Two Wars and Tito In-Between: The First Yugoslavs}

This chapter focuses on the First Yugoslavs, the oldest generation. The First Yugoslavs were born before WWII and were adolescents or young adults when Tito's Yugoslavia was established. The First Yugoslavs' discursive tactics show that the suffering caused by the war of 1992-1995 is likely to be embedded in a wider narrative of suffering, which starts before that war. Interpretative templates from WWII are taken to make sense of experiences during the recent war.

Owing to the experience of WWII early in their lives, the war in the 1990s did not seem to come as a total surprise for the First Yugoslavs. Even if it cannot be claimed that this generation expected the 1990s war, they were still more 'prepared' for it; they also knew that national identities can be radicalised and komšiluk (neighbourliness) endangered. One of my younger interlocutors once told me that her grandfather insisted on building concrete walls in their house to provide shelter in case of a future war. The younger family members always teased him about his quirky behaviour, but today they believe that he was actually right in distrusting peace. In addition, he had insisted that WWII was much worse in nature than the recent war my young interlocutor, his granddaughter, had experienced; nevertheless, this difference as a result of life experience does not

(C) The Editor(s) (if applicable) and The Author(s) 2016 
change the fact that the First Yugoslavs also suffered greatly during the 1990 s war. I by no means suggest that there is a scale of suffering according to generation.

Moreover, the First Yugoslavs' narratives are characterised by a reluctance to refer to clear-cut national identities and instead to retain other social demarcations, such as along a rural-urban divide. This will be discussed in relation to the idea of pravi Mostarci (true Mostarians). In the second part of the chapter, the discussion moves from the individual to a more collective level. Based on observations at a commemoration ceremony, I analyse how members of the First Yugoslavs generation engage in keeping the memory of the Partisan fight alive, while at the same time linking it to the recent war. At this commemoration ceremony, victims of the Croat NDH regime of WWII and victims of the Croat quasi republic Herceg-Bosna in the 1990s merge together as 'victims of fascism'. Thus the once multinational character of the Partisan commemoration has increasingly become a Bosniak commemoration, even if this is not at the attention of its key proponents. By supporting the Bosniak-dominant public discourse, the Partisan commemoration runs the risk of failing in its self-declared aim to fight not only fascism but also nationalism.

\section{Otvoreno srce}

At Otvoreno srce (Open Heart), a centre mainly funded by foreigners but locally run, ${ }^{1}$ is a place where elderly people can socialise and share a hot meal. Otvoreno srce is located in Zalik, a neighbourhood in East Mostar. ${ }^{2}$ Although it is situated in East Mostar, Otvoreno srce is explicitly open to people of all nationalities. A shuttle bus serves everyone, those living in the eastern as well as those living in the western part of Mostar. Otvoreno srce makes announcements on public radio stations to inform all elderly

\footnotetext{
${ }^{1}$ Based on an interview conducted with staff at Udruženje Žena B\&H (Association Woman B\&H), which runs Otvoreno srce.

${ }^{2}$ In 2010 Otvoreno srce moved to bigger premises in Tekija.
} 
people in Mostar of their activities. Although Mostar has several klub penzionera (senior clubs), these are mostly attended by men and are not nationally integrated. During weekdays, the elderly arrive at Otvoreno srce around $10 \mathrm{a} . \mathrm{m}$. and spend their day socialising. They engage in exercises for the body and the mind, play cards, drink coffee and enjoy an inexpensive hot lunch. There is also some exchange of home-made goods, from knitted socks to milk and bread. In the early afternoon the shuttle bus drives them back to their homes.

Otvoreno srce was clearly a place dominated by women, although a few men were present too. One can also tell that women had taken over the place by the way the walls were decorated with their hand-made embroideries and other handicrafts. Popular topics of discussion were prices (from that of vegetables to renting flats) and diseases and their cures. Personal problems and family issues, as well as local politics were also spoken about.

I received a very warm welcome at Otvoreno srce, where it seemed everyone was happy to have a new (and young) face around. From the beginning, the elderly people literally took me by the hand, patted my shoulder, whispered little secrets into my ears and invited me for coffee. Without expecting much in return, besides my presence, they almost treated me as if they were my grandparents. The staff also welcomed me, treating me like a new staff member. I was invited to lead the morning gymnastics and to introduce new games and other activities. Here, I was able to conduct participant observation in the full sense of the meaning.

\section{Nostalgia for Tito}

One day in March 2007, when I visited Otvoreno srce, I found five elderly women sitting on the big comfortable sofa, singing the following lines of the famous Tito song:

Druže Tito, mi ti se kunemo, mi ti se kunemo. Da sa tvoga puta ne skrenemo, puta ne skrenemo. Druže Tito, preko Romanije, preko Romanije. Ti odvodi svoje divizije, svoje divizije.

(Dear friend Tito, we swear an oath, we swear an oath. That we will not turn away from your path, we will not turn away from your path. 
Dear friend Tito, over Romanija [mountain in Bosnia], over Romanija. You take your divisions, your divisions.)

The women remembered the words as if they had rehearsed them every day over the past 17 years, dating back to when the statesman to whom this song is a tribute died. While singing it, their faces brightened and the song seemed to fill them with energy and joy. It obviously triggered strong emotions, coupled with memories of the 'good old days'. Research on musical memory has shown that older people in particular use familiar songs to revive moods from the past, which may intensify feelings of nostalgia (Van Dijck 2006). This was clearly the case with the women at Otvoreno srce. Immediately after the singing stopped, however, these pleasant memories became overshadowed almost, as if the women once again realised that these days were gone. A lively conversation arose among them:

Woman 1: There were Serbs, Croats, and Muslims in Tito's army. Together they fought for justice. That justice remains and we remain!

Woman 2: And if this would not have come over us, it would still be...

Woman 1: And until today... we would be together. But they came here and divided us. The Croats left there, the Serbs there. We... we were left to go nowhere.

Woman 3: Says a Mostarian [laughs].

Woman 2: A powerful state [Yugoslavia], the third most powerful in the world. And that had to be razed. And when it disintegrated... because there were Slovenes, Macedonians and all the others in Yugoslavia. And of course Croatia with Zagreb. This all was Yugoslavia.

I: Did you travel a lot?

Woman 2: Yes, of course, always! I still travel around today. One could go everywhere, everywhere, of course! One could go to Zagreb, one could go to Belgrade, to...

Woman 3: Back then there was no visa. There was no visa. There was...

Woman 2: There was no visa!

Woman 4: You could sleep on the bench on the street. Nobody would have done anything to you, not 'ha', not 'mu', even in the deep forest. Nothing would have happened to you, no one would have attacked you, let me tell you! And now you cannot even sleep peacefully in your house. You wait until someone comes for you, kills you. That's the way it is. 
Woman 1: There is no work. If there were jobs, if they would open factories, everything would be a little different. If one would care. [...] If the world would care! If people would have jobs, if factories were opened, I tell you how much more Mostar would be united.

Woman 4: I have three grandchildren. Not one of them works. No one works! Only their mother works, she cares, she cares, of course, what else could she do? What else could she do, she wants to provide her children with university education. What can you do?

This conversation came quickly, just after the cheerful singing had ended. It seemed as if the women felt a great urge to share their thoughts and opinions. The Tito song was a powerful trigger for memories as well as for immediate statements on present-day developments. As is made clear throughout, the narratives about Yugoslavia are never only 'memories' but always position the speaker in relation to recent developments. Whether the speaker wishes to make a political statement or not, the way one positions oneself vis-à-vis Yugoslavia always refers to the state of the present political and economic situation.

Let us now examine more closely the themes that were brought up in the conversation among the women at Otvoreno srce. The conversation started with praise for a strong and powerful Yugoslavia. Yugoslavia is remembered as a state that was strong to the outside world (in terms of international power relations) and strong within as it kept the different nations together. But then the women said that its strength was a thorn in the side of other powerful national and international actors, making it a target for destruction.

My question about travel, however, turned the conversation towards the women's personal experiences. The women stressed repeatedly that during the time of Yugoslavia there were no visa requirements, so they could travel freely. The freedom of movement associated with the red (Yugoslav) passport is sentimentally remembered by all those who today possess a (blue) $\mathrm{BiH}$ passport. Those of Mostar's Croats who hold a Croat passport face far fewer visa requirements than those who only hold a $\mathrm{BiH}$ passport, and are free to travel and to enter the EU. In 2009 the EU granted visa liberation to Serbia (but not to $\mathrm{BiH}$ ), which also allowed Bosnian Serbs holding a Serb passport freedom of movement. This development left those who were only citizens of $\mathrm{BiH}-$ mostly Bosniaks - at a great disadvantage. The visa liberation granted to Serbia 
and other Yugoslav successor states, but which excluded $\mathrm{BiH}$, fuelled the visa debate and provoked strong emotions. In this debate Bosniaks reacted to their disadvantageous position and claimed that these developments have led to a state where former war criminals (who are mostly still at large) are allowed to travel freely to EU countries, while victims of the war are locked inside their non-functioning country. Although I sympathise with Bosniaks' feelings of unfair treatment, it has to be said that these visa regimes actually create an 'atmosphere of entrapment' (Jansen 2009: 819) for anyone who is affected by it, regardless of nationality.

Returning to the women's conversation at Otvoreno srce, we see that the claim of freedom of movement previously experienced is immediately followed by their claim of now being fearful in their homes. I do not know how many times I have heard statements like this; that in the time of Yugoslavia you could sleep on the park bench, in the forest and so on and nothing would have happened to you. Such statements are commonly employed by the First and Last Yugoslavs, and serve as a metaphor to illustrate the feelings of security experienced during the time of Yugoslavia. I assume, however, that it is more than a metaphor for just physical security (in contrast to the physical threat of the wartime) but is rather an expression of an overall feeling of security (physical, social and economic).

At the end of the conversation cited, the women refer to the bad economic situation Mostar faces today. Here, again, the present situation is compared with Tito's Yugoslavia. Interestingly, one speaker draws a direct connection between the weak economy and high unemployment with the tensions between Bosniaks and Croats. This connection is interesting insofar as international observers more often than not simply reduce the dire relationship between Bosniaks and Croats to hatred. When we remember that Tito's goal of Brotherhood and Unity was coupled with the goal of prosperity, the women's awareness of this correlation may come from their experience of socialist times.

\section{Displacement and Loss of Family}

Although the subjects of children and family were often an easy way to engage in conversations with elderly people, I soon realised that talking about family could be a sore point in the elderly women's memories. 
Similar to the destruction of good neighbourliness, good family life was greatly interrupted and families were often dispersed on account of the war. Indulging in a conversation about children and grandchildren was likely to bring to the surface stories of loss and suffering. Many close family members, such as children, spouses and siblings, died during the war; most of the deaths were directly or indirectly caused by war. As I soon realised, even seemingly shallow conversations had the potential to reveal great wounds. Once, for example, I was sitting with a small group of people at Otvoreno srce when one woman said she liked the necklace with the small blue stone I was wearing. Thereupon another woman announced that she had a similar piece of jewellery that was stolen during the war. When she noticed my concerned look, she added that material things are unimportant and the only thing that counts are loved ones. She then recounted with a shaky voice and tears in her eyes that she originally came from Goražde and had lost her husband and one of her two sons during the war. The dead bodies of her loved ones had been thrown on a rubbish dump, so she was unable to say goodbye to them, and only saw on TV the mass grave where they found the remains of her husband and son.

When the woman from Goražde ended her story, another woman from Mostar followed on with hers. Her story started with the loss of her brother around 40 years ago. At that time she was pregnant, and the sad news about her brother's death caused the premature birth of her baby. As there were no incubators in Mostar's hospitals, the baby was transported to Sarajevo but did not survive the journey. Thereafter she lost three more babies. During the last war she also lost her husband. The 'Chetnics' killed him, she told us, so the only family she has left today is her father. Only when I got to know her better after several visits to Otvoreno srce did I learn that her husband was not actually killed by a Serb soldier, which I had assumed from her previous statement. She also later told me that she was in a mixed marriage, since she was a Bosniak and her husband a Serb (or at least these were the identities ascribed to them), while they actually saw themselves as Yugoslavs. During the entire war, her husband had to hide in their flat in West Mostar. According to her description, he was in constant fear for his life, which made him sick and resulted in his death. Although his death was not directly caused by the war, in her opinion the war nevertheless killed him. I heard similar stories from other bereaved 
people about deaths that were linked to the war even if the war did not directly cause them. ${ }^{3}$

It needs to be added that the stories about broken families revolved not only around the death of close family members, but also the absence of family members as a result of emigration (forced or otherwise). There is hardly a family in Mostar whose members all still live in $\mathrm{BiH}$. Many fled during the war to other Yugoslav successor states (especially to Croatia, Serbia and Slovenia) but also to other European and non-European countries. Many of them never returned to $\mathrm{BiH}$, especially the children and grandchildren of the First Yugoslavs. The wish to return was stronger among the First Yugoslavs themselves, and many of this generation said they were unable to learn the language or to become accustomed to the different mentality and climate with which they were confronted. Moreover, elderly people who fled the Yugoslav wars very much depended on their children, with whom they usually shared an apartment in exile, and their decision to return has also been affected by their concern not to become a burden to younger family members (see Leutloff-Grandits 2006).

The First Yugoslavs' longing to return home was so strong that they often grasped the first chance to do so once the war was over, hoping that the family they had left behind in the host country would eventually follow them. Many people of this generation moved back to their pre-war homes, even if it was now on the 'wrong' side. This is mostly true for Bosniaks who moved back to their flats in West Mostar. Overall, they said that they feel safe today but that komsiluk (neighbourliness) has changed (see Chap. 2). Their relationship with their neighbours has become superficial and is reduced to simply exchanging greetings. The pre-war coffee visits common among neighbours and the support they once gave one another is now lost, they say.

\footnotetext{
${ }^{3}$ During my stay in Mostar I became friends with a young Bosniak man whose parents had died shortly after the war ended. He blames their death on their strong political commitment to a united Mostar during the war in the 1990s and them holding on to the ideal of Brotherhood and Unity at a time when it was already clear that this would not be realised, even once the war was over. When they saw that even their closest friends had betrayed the ideal of a multinational Mostar, they became extremely depressed and lost their will to live.
} 
In order to reveal the specificities of the First Yugoslavs generation further, two persons, Danica and Armen, and their narratives will be introduced in the following sections.

\section{Danica: More than One Rupture in a Lifetime}

I met Danica at Otvoreno srce. Born in 1926, Danica was the oldest of the women I met at the centre. Only quite a while after I first met her did I learn that she is a Catholic. Interestingly, she did not refer to herself as 'Croat' but only as Catholic. It is not uncommon among the oldest members of the population to refer to the three 'nations' according to their religion-as Muslims, Catholics and Orthodox-as had been common before the rise of nationalism. While younger generations still use the term 'Muslim' and 'Bosniak' alternately, they no longer refer to Croats and Serbs as Catholics and Orthodox, respectively. This linguistic usage manifests clearly how identity categories have changed their meanings even within a lifetime.

Danica's parents migrated from Czechoslovakia to Sarajevo at the beginning of the 20th century, where she lived until she married a Mostarian and moved to his hometown. Today, she feels closer to Mostar than to Sarajevo since she has spent more than 50 years in Mostar. When Danica and I sat together, she liked to talk about the beautiful Mostar of the time when she was young. Central to her narratives were places where young people liked to spend time, among them the Old Bridge and šetalište (pedestrian street) at Rondo (today in West Mostar), and stories of a happy family life. In 1992, Danica lost most of her closest kin, including her husband, father, mother, brother and sister. A couple of years later one of her two daughters died. All of them, she said, died of a 'natural' death. Now she lives together with her daughter's former husband and her grandson. ${ }^{4}$

Danica's grandson is an active figure in a well-established youth NGO in Mostar. She is very proud of his being a public figure in Mostar, where

\footnotetext{
${ }^{4} \mathrm{In} \mathrm{BiH}$, where it is still relatively uncommon to move older family members to an old people's home. The elderly either still live in their own homes where they are looked after (mostly by a daughter or daughter-in-law), or if they cannot live independently anymore they move in with the family of one of their children or other younger relatives.
} 
he is even present in the media. Danica once told me with pride that both were asked by a local radio station to appear in one of its shows. They invited her to sing a traditional Sevdalinka. Danica had taken singing lessons and voice training when she was young and still likes to sing. Sometimes, she also sings for her friends at Otvoreno srce and they like to join in. She is most successful in animating others to join in her singing when she intones Tito songs.

For Danica, Mostar is closely linked with Tito, whom she will never stop admiring for what he achieved for her country, Yugoslavia. For her, like for many others of her generation, Tito is more like a saint than an ordinary mortal. When I once asked Danica what Tito meant for Mostar, she answered:

Everything, just everything! He was an extraordinary man, everyone thought that! Everyone liked him, everyone! He was, I don't know, I don't know, and he indeed was, also for the others, a brilliant man. Tito! They made a beautiful mausoleum for him. He truly was a man for the people, for the poor ones, for the gypsies. He did not care who was who but just cared for everyone, helped everyone as much as he could. He really was a great man! And as long as he was alive we lived, how do you say, ' $k$ o bubreg u loju' ['like a kidney in lard', meaning they had plenty of everything, similar to the English expression 'like a bee in clover'].

In Danica's eyes, Tito had committed his life to helping people live a worthwhile life and treated everyone equally, regardless of their ethnoreligious background. This is why she describes Tito's death as a great drama with one straightforward, unhappy consequence: the end of peaceful coexistence.

It might be easy to think that Danica must be very pessimistic about her country's future since the man who in her opinion held everything together had died. Interestingly, however, this is not quite true. Sometimes, I had the feeling with Danica that she somehow stands 'above politics'. When talking to her, I gained the impression that she did not consider the recent war was any of her business. Once, she said she still did not see why she should not be friends with a Muslim or an Orthodox. Indeed, Danica's best friend, who is also a regular visitor at Otvoreno srce, is Muslim. What binds them together is that they both 
grew up in Sarajevo and they both perceive themselves as true city dwellers; religion or national background to them is secondary.

Danica feels empowered enough to at least improve her life by coming to Otvoreno srce every morning to socialise with other women. Although a lot of her optimism is likely due to her personality, I observed that the First Yugoslavs compared to the Last Yugoslavs actually expressed fewer feelings of despair (see Palmberger 2008). As will become clear in Chap. 5, the Last Yugoslavs feel much more at the mercy of history and as if they have been caught off-guard by history more so than the generation discussed here. Moreover, it seemed to me that Danica also realised that, because of the long life she already has behind her, national categories are less primordial than they are said to be, but are instead artificial creations. She herself has seen how national categories suddenly appear (e.g., the category 'Muslim' in the national census) or change their meaning. It is the second time that she has experienced a war in her home country, including war among the Yugoslav people. While the situation looked grim after WWII, people somehow found a way to live together. Perhaps this experience gives her hope that what has been possible once will be possible again.

When Danica told me about the recent war, she often linked it to WWII. This she did in two ways. Firstly, through her personal experiences she remembers WWII as more threatening than the recent war. Secondly, she saw that the fight against fascism had to be fought twice, during WWII and during the recent war. Generally, WWII took a more prominent role in her narratives than the war in the 1990s. Moreover, it was interesting to note that Danica often misunderstood my questions if they concerned the war in the 1990s. When, for example, I asked her a question related to the recent war but only referred to it as 'the war', she assumed I was asking her about WWII and not about the war in the 1990s. During that conversation, I was speaking with her about Otvoreno srce when she said that it had become her second home; she always finds nice people there to talk to, regardless of their religious affiliations. When I asked her what they liked to speak about, she answered 'just about everything'. When I asked her if this included the war, she affirmed it and added:

I have to tell you, I remember this time better... and how it was during the war than let's say what happened here yesterday or the day before yesterday. It is just like that, that I simply remember it better! 
Were you in Mostar during the war?

Yes I was, yes I was. Half of the time in Sarajevo and half of the time in Mostar. In Sarajevo I met my husband. He was a sports official. And I married him, he was a Mostarian. And when I married him we moved to Mostar and there I stayed.

From her last sentences I realised that Danica was elaborating on WWII and not on the recent war. I realised that I had to explain myself better when speaking with someone who was old enough to hold vivid memories of WWII. In contrast, in conversations with the younger generations it seemed self-explanatory to them (and to me) that 'the war' referred to the war of the 1990s. For Danica, memories of WWII are very present, often more present than the immediate past.

While the narratives of the Last Yugoslavs all circle around the turning point of the 1992-1995 war and are classified either as stories of 'before the war' or 'after the war', this is not the case, at least not to the same extent, among the First Yugoslavs generation. This is because the war in the 1990s is not the only disruption in the oldest generation's lives around which their narratives are structured. Most of them possess very vivid memories of WWII. In conversations with Danica, I realised that WWII and the fear she went through during that time occupied her thoughts more than the recent war.

That the memories of the Last Yugoslavs were less marked by the war in the 1990s became also visible when initiating an activity at Otvoreno srce, asking the participants (including Danica) to name the most important places in $\mathrm{BiH}$ and later in the entire former Yugoslavia. In a second round I asked them to tell me their memories of these places from the time when they were young and their associations with the cities and towns I had drawn on the board. In a third round I asked how these places had changed in the intervening time and how they look now. The elderly people were all women, aside from Adis, a self-declared Yugoslav and atheist. All were very engaged in the activity and first named many cities and towns spread all over Yugoslavia. These places were then associated with a lot of different things, for example, nature (vegetation, mountains, lakes and so on), the local industry or local specialities. When I finally asked them how these places had changed since when they were young, their 
answers were strikingly apolitical. For example, they said that one place had become more polluted or another place had more car traffic now than when they were young. Only at the end of the exercise did Adis, who stood slightly apart from the others, say that one of the towns is now populated mainly by Serbs while before the war the Muslim population had been in the majority. I was amazed that this was the only politically critical contribution during the entire exercise, since many of the places written on the board have seen extreme violence and severe population shifts. I, for my part, had associated many of the places with the war in the 1990s, for example, with detention camps, which I had learned about through news coverage during the time of the war or from reading about them later.

One could argue that the older people had purposefully avoided associating the places with war and atrocities in order not to offend anyone in the room. However, I had listened to politically controversial conversations at Otvoreno srce before, when I was amazed by how openly people attacked one of the former war parties. While not precluding that this was one of the reasons for the participants' apolitical behaviour, I strongly believe that it is neither the only reason nor the most decisive one and that it is first and foremost connected to their generational positioning as will be discussed below.

The second of the three individuals belonging to the First Yugoslavs I discuss in this chapter is a man whom I met during my first visit to Mostar and with whom I kept in contact over several years. From his narrative we learn about his powerful identification with Mostar and its history, which was particularly strong among those belonging to the First Yugoslavs generation.

\section{Armen: A 'True Mostarian' Embedded in Local History}

I met Armen for the first time during my first visit to Mostar in 2003, when I rented a room from him. When I finally moved to Mostar with my husband and our twin sons, he eventually hosted all of us. It was a pleasure to live at his house for several weeks because of his kind and 
humorous nature, and because of the many stories he shared with us. As I soon found out, Armen's house has an open door policy, not only welcoming foreigners but also German language students studying at the nearby university Džemal Bijedić. His young friends provide him with company and he in return provides them with local culinary treats as Armen is a gifted cook. As a former German teacher, he was also able to help with language issues.

Armen has spent his entire life in Mostar, with only a short interruption during the 1990s war when he first fled to Croatia for a few months and then to Turkey where he stayed until 1996. He is still grateful to Turkey for hosting him during the time of war. Armen originally studied German and his German is still excellent even if some words sound antiquated. It must be said that Armen is no exception among his generation, one that still feels a strong bond to the former Austrian-Hungarian monarchy. I encountered a man in Sarajevo who illustrates this connection very well. He was a child during the end of the Habsburg occupation and was sent to Austria by his father every summer to improve his German. When sharing his memories with me, we shared a Viennese Sachertorte (typical Viennese chocolate cake) and drank coffee in a café in Sarajevo's Old Town called Wiener Café. It was touching for me, as an Austrian, to see these old bonds between Austria and $\mathrm{BiH}$ still sustained in this old man who spoke old-fashioned Austrian German and incorporated the so-called Viennese-School in the way he conducted himself. The Viennese café, on the other hand, I recognised as a place for reviving old bonds for a 'new' Sarajevo identity.

Armen's strong bond to the German language is also connected to the Habsburg history, which he 'remembers' as a good period for Mostar and all of $\mathrm{BiH}$, although, in contrast to the man I met in Sarajevo, he holds no personal memories of it but only memories transmitted to him by older family members. Armen is an experienced city guide and several times I had the pleasure of walking around Mostar with him. It was fascinating to see how he revived the history of the buildings and places we visited. It must be said, though, that his tour always only covered East Mostar. He did not make this an issue, as if it was self-evident why we did not cross over to West Mostar.

According to Armen, Mostar has a long history of occupation that continues to this day. 'We have always been under occupation', he said, 
'first under the Ottomans, then under the Habsburgs, then under the fascists and now under the Europeans!' Of the first two occupiers- the Ottomans and Habsburgs- he painted an entirely positive picture. He emphasised their achievements, especially the harmonious coexistence of $\mathrm{BiH}$ 's different religious groups during the Ottoman occupation and the great architectural realisations of that time. He praised the Habsburgs first and foremost for the construction of public buildings (e.g., schools and hospitals) and infrastructure (e.g., roads and railways). When he spoke of Kaiser Franz Josef and his heir to the throne Franz Ferdinand, he almost sounded sentimental. He still remembered the positive feelings old people held for the Kaiser. He also told me that Mostarians warned Franz Ferdinand not to travel to Sarajevo but that he, unfortunately, did not heed their advice. Armen is sure that a great number of Mostarians were deeply upset when they learned about the assassination of Franz Ferdinand and his pregnant wife by 'Serb terrorists'.

When on our tours we finally arrived at the Stari most (Old Bridge), Armen revealed a great repertoire of stories about it including legends about its construction (and destruction) and its meaning for Mostar. He made it clear that he was still upset about its destruction. Stari most survived WWII, Armen told me. When the Italian fascists planned to blast it the Partisans prevented the demolition by cutting the fuse just in time. To his great sorrow, the Croats managed to destroy the bridge in November 1993. The stari (as he sometimes liked to address the Old Bridge as if it were human, an old man) was a place of his youth. This was a common sentiment among many others of his generation (regardless of their nationality) who remembered the Old Bridge as a meeting point for young people, where often memories of first romances are tied to the famous bridge. As we have seen in the case of Danica, for Croats of this generation the bridge is likely to possess a similar importance as it does for Bosniaks. As such, it is clear that Croats of this generation have not taken on the dominant Croat discourse that distances itself strongly from the Ottoman past. The importance of the Old Bridge among members of this generation, regardless of their national background, suggests that the emotional bond that connects Armen with the Stari most cannot be reduced simply to his Bosniak identity (Fig. 4.1).

Armen perceives and presents himself as a pravi Mostarac (true Mostarian). He has a long family history in Mostar. When he talks about 


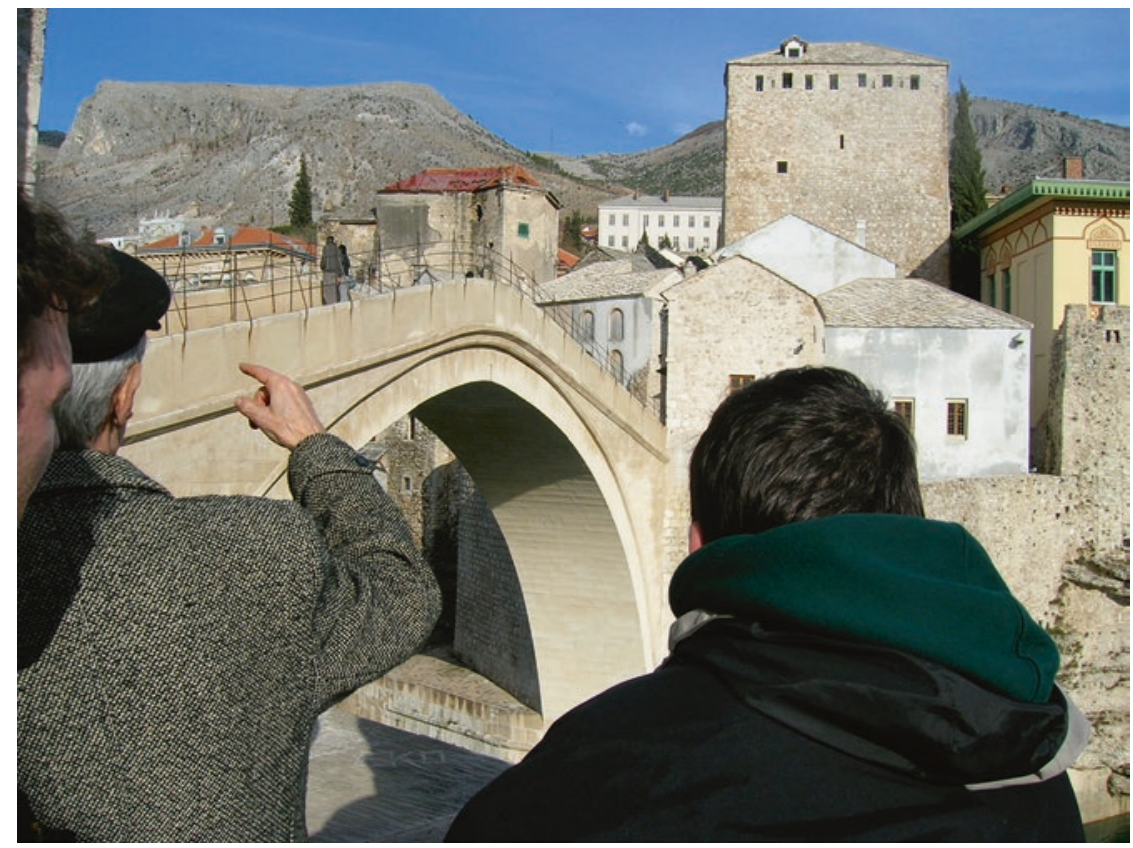

Fig. 4.1 During one of the memory-guided city tours with Armen, at Stari most. Photo by the author

pravi Mostarci (true Mostarians) he does not refer to everyone born in Mostar but only to those belonging to the well-educated pre-war elite. Most of them left the country during the war and did not return, but there still is a small number who remained. Armen often expressed his dislike of present developments in the city in statements such as 'Mostar used to be a small city but today it is a big village!', an expression I have often heard from so-called pravi Mostarci. With such statements my interlocutors blamed the refugees who came from rural $\mathrm{BiH}$ to settle in Mostar for spoiling the city with their uncultured behaviour. They also linked the decay of good neighbourliness to the newcomers. This is a phenomenon not restricted to Mostar, but one that can also be found in other places in BiH (see Helms 2008; Jansen 2005; Maček 2009; Stefansson 2007).

The group identity of pravi Mostarci is strengthened through local activities, such as celebrations of local artists. One of these celebrations I joined was dedicated to Aleksa Šantić (1868-1924), a Bosnian-Serb poet 
who lived most of his life in Mostar. Through his poems he attempted to overcome national boundaries and provide a pan-Slavic vision. Although at the ceremony in question that took place on 2 February 2006, the wreath ceremony was organised by the head of Mostar's Serb cultural centre (Srpsko prosvjetno i kulturno drustvo prosvjeta), the small group of people who attended were of different national backgrounds. The people present were in their 50 s to 80 s. From an earlier conversation with the head of the Serb cultural centre, and from an Orthodox Christmas celebration I had attended, I knew that the Mostar's Serb cultural centre viewed itself as a place open to all nations interested in Serb culture and arts.

The ceremony in question took place on the 82nd anniversary of the writer's death. But before commemorating Šantić, another local poet, Osman Đikić, was remembered at his honorary grave, which is located close to the Old Town in East Mostar. Šantićs grave, which was visited next, is located at the Orthodox graveyard on the hills in East Mostar, close to Mostar's Orthodox cathedral which was destroyed during the war (Fig. 4.2).

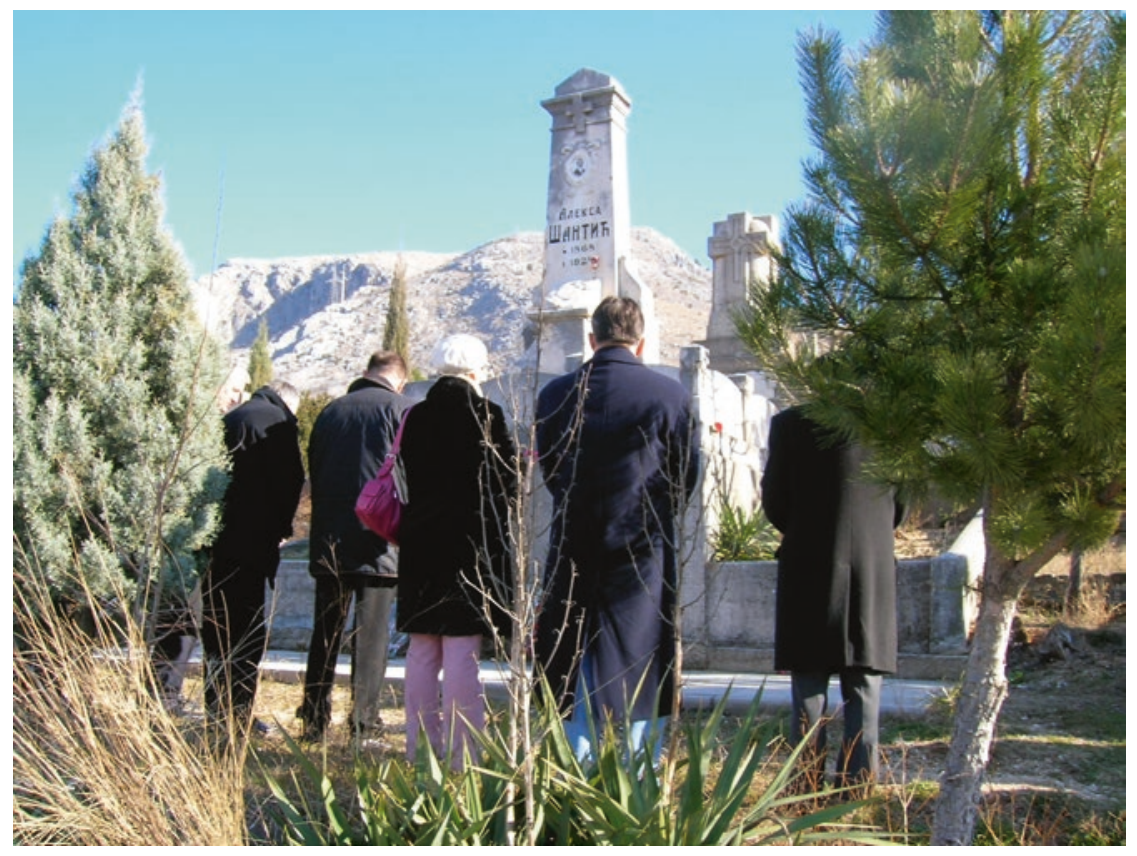

Fig. 4.2 At the anniversary commemoration of Mostar's poet Aleksa Šantić, 2006. Photo by the author 
After the ceremony, which I attended together with Larissa Vetters, another anthropologist, we conversed with the participants. They were very open and interested in our research projects and particularly liked the idea that I was interested in memories of Mostar. Without further questioning, our interlocutors were sure that I was interested in learning about the true Mostar, 'Mostar's soul' as they put it. This, they assured me I would only find if I spoke with public figures who had been active in politics and culture in pre-war Mostar. My interlocutors became so excited about this that they wrote down a list of people whom I should contact. This list solely included public figures from pre-war Mostar, such as mayors, poets and artists. Afterwards, they took us on a tour through the Old Town where they introduced us to several artists. On this occasion, we also visited the studio of Jusuf Jusa Nikšić, a local painter, who invited us for a drink (local rakija). At the end of our tour visiting pravi Mostarci one of our 'guides' told us in a dramatic voice that it will take decades to educate the rural newcomers on how to behave in a city. Thereupon he said that Mostar experienced something like Hiroshima and, accordingly, will take a long time to recover.

Although Armen did not take part in the particular ceremony described, it is the same 'Mostar's soul' that he and the participants at Šantić's commemoration cherish. Even if this local identity is not confined to the First Yugoslavs, it is possible to say that it is particularly strong among them. In the cases of Armen and Danica, local identity, at least at times, even overcomes national identity. This shared local time also implies a shared generational past crossing ethno-national borders.

Summarising, we can say that the First Yugosalvs' narratives show more coherence and are less ruptured than the narratives of the Last Yugoslavs discussed in the next chapter. Furthermore, they are less penetrated by the present dominant public discourses than the narratives of the younger generations, the Last Yugoslavs and the Post-Yugoslavs. Due to the farreaching experiences connected to their age, the First Yugoslavs have a sense of the constructedness of nationality. This gives them-at least at times-the possibility of resisting the present rigid use of national categories. For example, religious and local identities among this generation are still prominent, but a Yugoslav identity, tightly connected to Tito, 
also prevails among the First Yugoslavs. Moreover, the First Yugosalvs are more optimistic that the different groups will live peacefully together in the future. This more optimistic outlook than their younger co-patriots is likely to be connected to their experiences of the post-WWII period, when the different ethno-national groups found a way to live together peacefully. Furthermore, nostalgia among First Yugoslavs for a shared time was less painful than for the Last-Yugoslavs and gave the narratives of the former a potential optimistic outlook that things will improve.

The First Yugoslavs' reluctance to current national politics and developments is also related to the particular life situation they find themselves in. In contrast to the Last Yugoslavs, who are in mid-life, have to make a living and often are responsible for caring for children (and for their parents too), the First Yugoslavs are not entangled in local post-war everyday politics in the same way. The First Yugoslavs find themselves in a period of their lives that allows them to delve into the past much more than the two younger generations, resulting in a strong feeling of a shared generational past (with special emphasis on Tito's early Yugoslavia). They also felt freer to return to their pre-war homes (even if they were on the 'other side' of the city) and to find spaces to cherish the (multinational) past with others of their generation, as at Otvoreno srce or at the Partisan commemoration day that is the subject of the rest of the chapter.

Of course, we have to consider that I met many of this generation at Otvoreno srce, a place where all nationalities are welcome. It therefore attracts people who do not perceive nationality as a strict line of division and this means that I was likely to meet a disproportionately high number of people of this generation who resist rigid national categorisation. Moreover, none of my key interlocutors of this generation was loyal to the Croat NDH regime of WWII. Notwithstanding all this, it became clear that for the First Yugoslavs national identity is not such a powerful categorisation as it is for the Last Yugoslavs and the Post-Yugoslavs, even if compared to those of younger generations who I met at places as mixed as Otvoreno srce. It is certainly not the exclusive privilege of the First Yugoslavs to resist and challenge Mostar's national division. 'Border crossers' can be found among all three generations as shown elsewhere (Palmberger 2013a). 


\section{Remembering the Partisan Past: Old Form, New Meaning}

Mostar still has a Partisan association with mainly elderly members. ${ }^{5}$ It is one of the SUBNOR (Savez udruženja boraca Narodno-oslobodilackog rata, The Federation of Associations of Veterans of the National Liberation War) that existed in former Yugoslavia. The president of SUBNOR of Herzegovina-Neretva Canton is Alija Bijavica, a man in his 80 s who is easily identifiable from his appearance and the way he acts and communicates as a member of the pre-war urban elite. He has been president of the canton corpus of anti-fascist fighters for the last 15 years and was a president at the city level before. As I learned during a conversation with him, the Partisan ceremony has taken place every year since WWII, with the only exception being the years 1992-1995 when the war made it impossible to organise the commemoration. Although it was continued after 1995, today it receives little media attention in contrast to the newly established national commemorations for victims and heroes of only one nation. Still, I noticed an increase in media presence at the commemoration compared to 2006, perhaps a sign of its increasing political relevance. Interestingly though, the Partisan commemoration attracted more participants than some of the newer commemorations I attended during my fieldwork. Notes taken from my Mostar field diary on 14 February 2008 read:

Arriving at the meeting place shortly before the official opening of the ceremony at 10:30 a.m., I see only a few elderly people gathered around the bust of Mustafa Čemalović Čimba (1919-1943). Čimba is one of the people's heroes who lost his life fighting against the Nazis. His bust is situated on the western bank of the Neretva River, but just below the Bulevar and so is still located on the Bosniak-dominated east side. Another 15 people are waiting at the other side of the road, chatting and laughing. The commemorators are predominantly elderly people, some of them in festive, others in casual, clothes. Most of them are in their 70s, 80s or even 90s, which means

\footnotetext{
${ }^{5}$ In present $\mathrm{BiH}$ about 25 Tito associations exist including around 8000 members (Halder 2013: 280).
} 
they were teenagers or young adults during WWII. A few minutes after my arrival, pupils from the school located just next to the bust join us with two teachers. The pupils, around 10 years old, queue neatly behind the bust.

After the children have organised themselves, a man rises to speak. $\mathrm{He}$ extends welcoming words, followed by a brief introduction of Čimba and his struggle against fascism. We learn that the German army entered Yugoslavia in 1941 and from this day until the liberation in 1945, 70 Partisan fighters received the honorary title narodni heroj (people's hero), one of them being Čimba. During those four years, 800 soldiers gave their lives for Mostar and its people in order to obtain freedom, the speaker tells the audience. The youngest generation, he says, has to learn about Yugoslavia's history and must not forget it because today Mostar is again confronted with these 'roots' of fascism. At the end of his rather lofty speech, a pupil lays a wreath before the bust.

The next speaker is an elderly woman. She is small and wears her white hair unconventionally short. Although still agile, one can see by the wrinkles on her face that she has a long life behind her. I later discover that she is 84 years old and head of the local Partisan women's organisation. She begins her speech by loudly calling out the well-known Partisan slogan: Smrt fašizmu, sloboda narodu! ('Death to fascism, freedom for the people!'), whereupon the children are urged to applaud. She continues that Čimba, like all the other soldiers, did not fight for his own benefit but for Bosnia and the entire Yugoslavia. Then she tells the pupils about life in Tito's Yugoslavia where everyone lived together and people did not odmiksali (separate themselves, literally 'de-mixing') like they do now. She stresses the importance of history and, while pacing slowly, step by step, she addresses the pupils:

Step by step. We can learn what we have already learned. History can teach us. We have learned once already from history and today we have to learn from history again. In order to know who we are, what we are and where we are. We are the people (narod) of Bosnia and Herzegovina!

At the end of the speech, she calls upon the teachers to teach their pupils how people lived together during the time of Yugoslavia and not to teach 
them to live divided. To loud applause, she is warmly received by her female friends who start greeting her with a well-known Tito song. The friends hug and kiss each other, obviously entertaining memories of Yugoslavia. The atmosphere is cheerful, with the singers clapping their hands to the rhythm of the song. Some pupils look bewildered by the singing women, while some start cheering. Before the crowd moves on to the next stop, a friend of the female speaker shouts once again: 'Smrt fašizmu, sloboda narodu!' and everyone claps their hands. When we leave the first stop I spy a fleur-de-lis at the back of Čimba's bust. Someone must have drawn the symbol (closely associated with the Bosniak nation) on the bust of the Partisan hero.

I am surprised to see the next stop is not a Partisan commemoration site but the martyrs' cemetery. At Šhitluci, as it is commonly referred to, (Muslim) 'martyrs' who fought 'for the liberation of Mostar' between 1992 and 1995 are buried. Before the war there were only a few old Muslim tombstones. Today, Šehitluci is the central place in Mostar for commemorating the Bosniak victims of the 1990s war. More than a hundred additional commemorators are already waiting at Šehitluci, among them the organiser, Alija Bijavica. Two buses have been provided for the participants - a yellow bus donated by Japan usually in service for regular public transport-and one from the delegation from Konjic, a town an hour from Mostar on the way to Sarajevo. Behind the windscreen of the latter bus I see a somewhat oversized photo of Tito, a suggestion perhaps that the former leader is overlooking the ceremony from a distance. Some of the people carry Tito closer to their bodies, like an elderly man who has Tito's portrait pinned on a button to his coat. Two elderly men (both from the Konjic delegation, as I later learn) are leaning against the wall at the entrance to Š hitluci, distributing little Tito card calendars. On the front of the card is a Tito portrait and on the back a calendar of 2008 with a logo of Forum Mladih SDP BiH (Forum of the Young Social Democratic Party BiH).

The head of the local Partisan women's organisation now holds a big Bosnian flag in her hand, which she then wraps around her shoulders and wears like a big cape. The blue and yellow flag with the white stars suits her well and she does not take the flag off again during the entire ceremony. She is very cheerful and obviously enjoys being unconventional. 
But the other commemorators also enjoy her entertaining contribution. Together with the other commemorators I gather around a commemoration stone (the same stone where the school classes met before they attended the history lecture under the Old Bridge; see Chap. 3). Alija Bijavica addresses the commemorators with only a few words, saying that now the victims of the second fascism will be remembered; his words are followed by a 'slave mu' ('slave mu' ends Muslim prayers, like amen ends Catholic ones). The people next to him assume the Muslim prayer pose. In front of us a quote from the Qur'an is inscribed in the stone:

I ne recite za one koji su na allahovom putu poginuli: 'mrtvi su!' Ne; oni su živi, ali ne osjećate (Kur'an: 154).

(Do not say of those who are killed in the cause of God, 'They are dead.' They are alive at their Lord, but you do not perceive (Qur'an: 154). ${ }^{6}$

Above the text a fleur-de-lis has been inscribed. It is similar to the one I identified on the back of Čimba's bust. On my way to the bus I pass a reporter from Federation TV who asks Alija Bijavica to provide a message to the people of Mostar. I find it remarkable that the head of the Partisan association is given the opportunity to make a statement to the people of Mostar this way.

The next stop is Musala Square, a central square located in East Mostar, bordering a bridge over the Neretva River. Several significant buildings around Musala Square have been ruined during the war, such as the Hotel Neretva, the music school and the city's swimming pool. All were buildings from Austro-Hungarian times and all apart from the pool are still in ruins. Musala Square is a small renovated park which hosts several memorials erected in different decades. Considering the small size of the park, far too many memorials are placed there. The commemorators pass the Partisan memorial at the entrance to the park and continue to the two busts of Partisan fighters behind it, where flowers are laid. On the left side stands the bust of the narodni heroj Mladen Balorda (1921-1945) and on the right side the bust of narodni heroj Hasan Zahirović Laca (1920-1943). The busts of the two Partisan fighters face another, very

\footnotetext{
${ }^{6}$ English translation retrieved at http://www.submission.org/suras/sura2.html [12.09.2010].
} 
modern memorial with the inscription: 'Commemorating the friendship between the people of Kuwait and of BiH'?

Finally, the buses drive the commemorators to the biggest Partisan commemoration site in Mostar, the Partisan memorial cemetery built between 1960 and $1965 .^{\circ}$ During the entire bus ride several of the passengers sing Tito songs at the top of their voices. The atmosphere is lively and one woman intones one song after another, all the while waving her red carnation out the open window. The bus passes heavily shelled buildings on the Bulevar and then crosses to the Croat-dominated part of the city. Just when we enter West Mostar, the woman with the carnation in her hand starts a new song with the refrain saying: A na drugoj strani, a na drugoj strani, a na drugoj strani. Napred partizani! ('But on the other side, but on the other side, but on the other side. Move ahead Partisans!'). She almost screams the words out of the windows, making clear who she means by 'the other side'. Pedestrians passing by look either bewildered or amused when they notice the bus full of elderly people singing old Partisan and Tito songs. The bus stops close to Sveucilište's campus and we only have to cross the street to enter the Partisan memorial cemetery.

In pre-war Mostar the cemetery was one of the main tourist sites. A travel guide (Njavro 1985) of Herzegovina published in 1985 even suggests that tourists join the celebration on 14 February. During my stay in Mostar, I met several elderly Bosniaks who told me about the Partisan memorial's former beauty and how proud they were to present it to foreign visitors. Today, many people do not even want to be seen there because it is said that only drug addicts frequent the place. One of my young Croat acquaintances even refused to enter the memorial site when he took aroup of Viennese university students on a guided tour through Mostar.

The procession slowly approaches the top of the memorial as the path is uneven and difficult for the elderly participants. On the way we pass much graffiti sprayed on the surrounding walls, among them Ustasha

\footnotetext{
${ }^{7}$ The memorial was erected in 2001, after the city of Mostar received a loan from Kuwait for rebuilding its infrastructure, including Musala Square.

${ }^{8}$ The initiative for the memorial came from former prime minister Džemal Bijedić. It was then realised by Bogdan Bogdanović, an architect, artist and mayor of Belgrade from 1982-1986, who designed numerous Partisan memorials in former Yugoslavia (Mutevelić 1980). Bogdanović left the country in protest against Miloševićs politics.
} 
symbols. The ground is covered with splintered glass from broken bottles and with every step I make I hear glass grinding between my shoes and the ground. On the way, I take the opportunity to speak to Alija Bijevica, the organiser of the ceremony. With a sigh he tells me that before the war there were 18,000 Mostarians present at this ceremony, while today there are only about 150 people. I also learn from him that the Partisan memorial cemetery was the site of big protests against the upcoming war in March 1992. After telling me about the beginning of the war in 1992, he returns to WWII. Back then, every third Mostarian fought for the liberation, he says, and every eighth did not see the day of liberation. 'This is why we are fighting against fascism, because the fascists ruined everything', he concludes.

At the top of the hill I meet his wife, a well-dressed woman, like her husband easily recognisable as a member of the pre-war urban elite. I stand next to Mrs. Bijavica, both of us looking down at the Partisan site when she tells me about the way the Partisan memorial looked before the war. It used to be one of the first sites tourists would visit, she assures me like many others before. 'And look what happened to it!' she says in a sad tone, pointing towards the memorial. Indeed, the memorial site is in poor shape: the path is dirty and covered with pieces of broken glass, the stones of the memorial are covered with moss, many are loose and there is offensive writing on the walls. It was the architect's purpose to integrate the memorial into the landscape, but now it seems as if the landscape is taking over the memorial.

The 750 white headstones have softly curved shapes, as do the inscriptions which give the names of the dead and their places of birth and death. But even the stones have not been spared decay and vandalism. Many of them have been broken and forcibly removed from their original places. One old man is obviously disturbed by the bad shape they are in. In a seemingly endless attempt to restore the site back to order, he gathers piece upon piece of broken headstones to set them together again. The woman who gave the speech at the first stop searches for the stone of one of her relatives but does not find it. Other commemorators who are lucky enough to find where their loved ones are buried put red carnations on their stones (Figs. 4.3 and 4.4).

At the top of the memorial some 150 people gather in a semicircle. After some commemorators lay down flowers and wreaths (some of them 


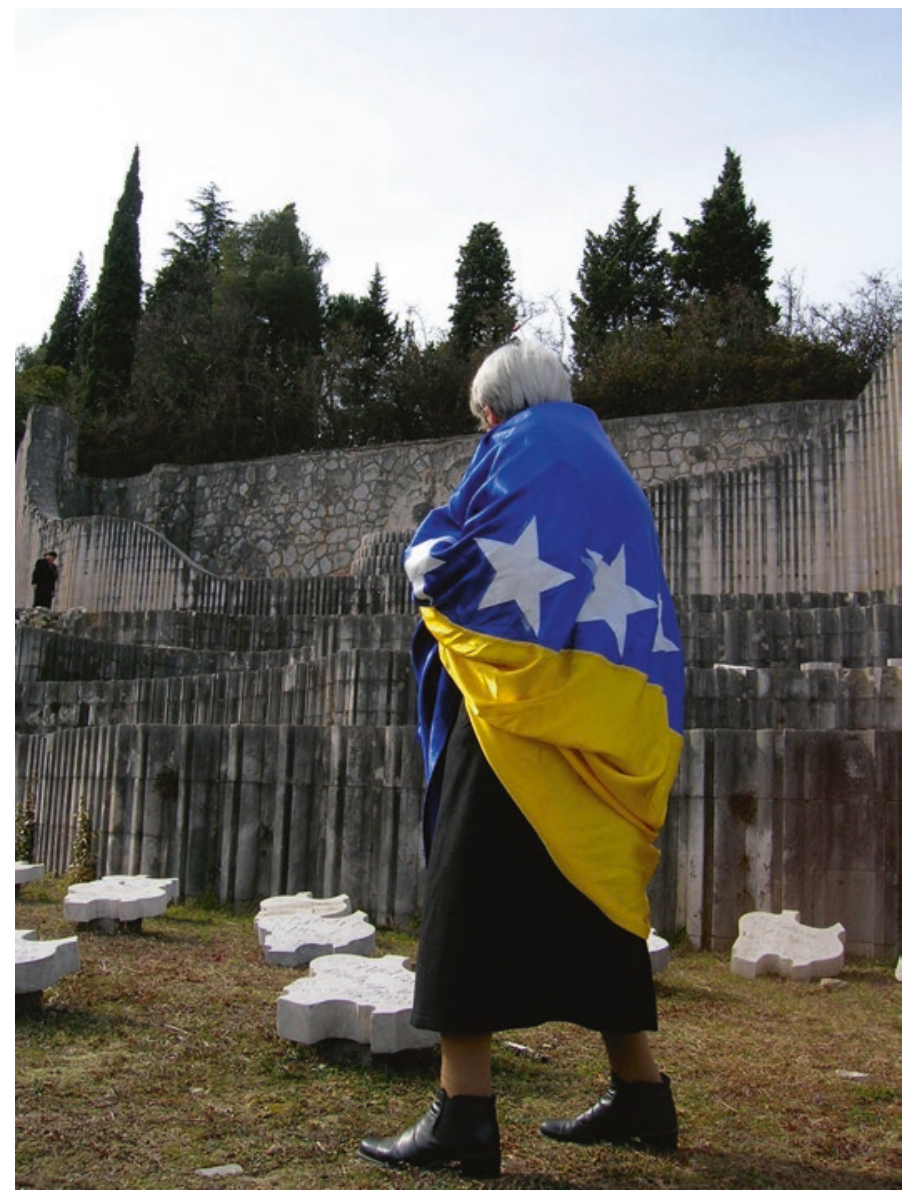

Fig. 4.3 Partisan commemoration ceremony, 2008. Photo by the author

pausing for prayer), Alija Bijavica begins his speech in which he calls for 'the sons of our town' who fought for its liberation never to be forgotten. Alija continues to praise the great solidarity Mostarians showed with Serbs, Jews and Roma who became victims of genocide. This Partisan memorial used to be our national memorial, he says, until the nationalists came in March 1992 and started to shell Mostar. At the end of his speech Alija appeals to those present to fight for a secular state. In his view $\mathrm{BiH}$ 


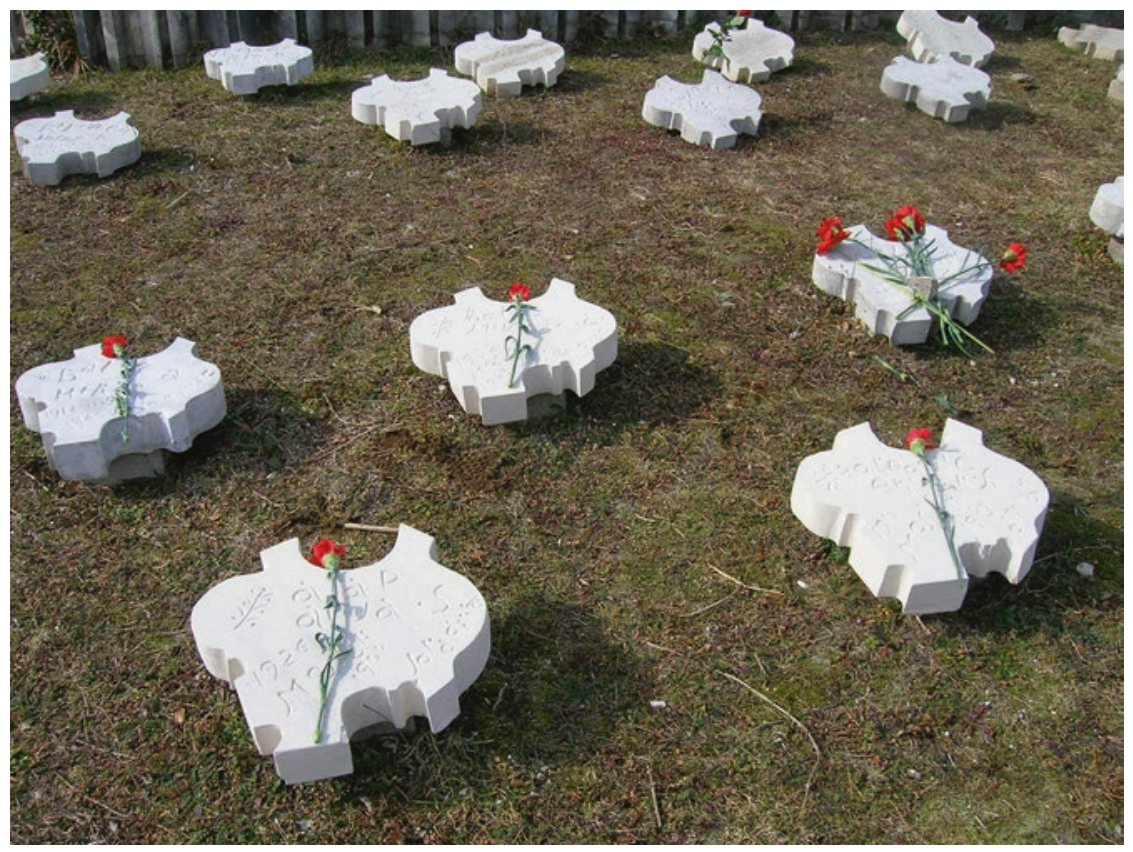

Fig. 4.4 Partisan commemoration ceremony, 2008. Photo by the author

is only a step away from becoming a religious state. But the future of $\mathrm{BiH}$, he says, is as a secular state that becomes a member of the European Union. At the end of his speech, Alija tells the audience about his plans to maintain the memorial site by building a fence around it and installing big floodlights to make it secure, although he faces obstacles since all energy is now put into erecting nationalist memorials. But one day, he says, the memorial site will look like it used to, and at these final words he receives resounding applause. ${ }^{?}$

The final stop is the alternative youth cultural centre, Abrašević, where we are invited into the theatre hall. When we enter the hall, which has been painted black, Tito songs blast out of the speakers, occasionally

\footnotetext{
${ }^{9}$ During my last visit to Mostar in 2010, the Partisan memorial cemetery finally was in the process of being renovated.
} 
interrupted by short sequences of one of Tito's speeches. Obviously recognising the songs, the old people smile, clap or sing along. I realise that a woman sitting in the row before me has tears in her eyes. On one occasion, at the end of a sequence of Tito's speech where the audience on the recording applauds, people in the present audience applaud, too. I feel somewhat uncomfortable because the old recording of Tito's speech, spoken in a very 'authoritarian' tone, reminds me too much of totalitarian political propaganda. After some 10 minutes, the music is turned off and the young host of Abrašević starts his speech by wishing the audience a happy holiday (sretan praznik). He says that we should never forget the war of liberation fought in WWII and that the fight against fascism is also a constitutional part of the youth centre's identity. But he says that he is aware that the participants at the centre are in the minority, so he invites the audience to tell young people about the way they used to live under Tito and the ideals they lived for. The generations should not stay divided but should engage in exchange with each other, he concludes and then gives the floor to Alija Bijavica, who ends the ceremony with a meticulous description of the Partisan fight for Mostar's liberation. At the end of the speech and three hours of the programme, the participants seem tired and glad to enjoy themselves over a drink in the company of old friends.

Remarkably, during the entire ceremony there was no explicit explanation or even the attempt to explain who the 'new fascists' are, i.e., who this frequently used term refers to. Although the organiser and central figures of the commemoration made relatively clear in their speeches that fascism/ exclusive nationalism is not restricted to one of the national groups in $\mathrm{BiH}$, the strong link to the $\mathrm{ABiH}$ found in the same commemoration gives room for other interpretations. When the woman in the bus waved her red carnation out of the window screaming 'But on the other side, but on the other side, but on the other side. Move ahead Partisans!', it was also clear that to her the enemies (fascists) were on the Croat-dominated west side while the (new) Partisans were on the Bosniak-dominated east side.

Every speech given at the ceremony included an element (in the speech itself, in the choice of venue or location, or in the symbolism employed) linking the recent war with WWII. Starting at the first stop, the speakers established a direct connection between the atrocities Mostar witnessed 
in the 1940s and those of the 1990s. This comparison is made twice: first, to warn the pupils present at the ceremony about the fascism Mostar again faces today and second to convince them that $\mathrm{BiH}$ can overcome national divisions as it has done so once already in its history after WWII. The organiser and head of SUBNOR makes this comparison again in his final speech at the Partisan memorial cemetery, where he indicates that the Partisan struggle against fascism has not yet ended.

During the ceremony I noticed many 'identity markers' that made it an event primarily intended for Bosniaks. First, the event visited Šhitluci, which is the place where most commemorations for Bosniak war victims take place. For example, I had previously attended three other ceremonies clearly Bosniak-led at Šhitluci: the commemoration on 9 May, a reburial of fallen $\mathrm{ABiH}$ soldiers and a protest rally against the ruling of the International Court of Justice on the charges brought forward by $\mathrm{BiH}$ against Serbia and Montenegro for committing genocide. ${ }^{10}$ Already during the war, fallen Muslim soldiers were increasingly referred to as $\check{s}$ ehids (religious martyrs). Bougarel interprets this upcoming $\check{s}$ ehid cult as a political strategy by the SDA leaders 'to use the war dead to homogenize the Muslim community and to claim a monopoly on the interpretation of the war itself [...]' (Bougarel 2007). Beside the Muslim martyrs' cemetery I noticed other signs during the Partisan commemoration suggesting that it is losing its multinational character. At almost every memorial site a 'slave mu' was spoken after the wreaths had been laid down or after a minute's silence had been observed. I never heard the Croat equivalent of 'amen'.

Another symbol strongly associated with Bosniaks is the fleur-delis that was drawn on Čimba's bust and also inscribed on a gravestone together with a quote from the Qu'ran about the immortality of martyrs. This fleur-de-lis was chosen as a supra-ethnic symbol for BiH's coat of arms in 1992 due to its pre-Ottoman origin in the Bosnian Kotromanić Dynasty which represented no particular ethnic group. During the war

\footnotetext{
${ }^{10}$ In April 2006, BiH presented evidence against Serbia and Montenegro in the first trial on genocide held before the International Court of Justice. When the judgement was announced in February 2007 acknowledging genocide only for the killing of around 8000 men and boys in Srebrenica in July 1995 and did not find Serbia-Montenegro responsible for the actions of the Army of the Serb Republic (VRS), several protest rallies were held all over $\mathrm{BiH}$, including Mostar.
} 
it became a symbol strongly associated with the $\mathrm{ABiH}$, which used the fleur-de-lis as its official sign (Kolstø 2006: 6). ${ }^{11}$ The fleur-de-lis not only became the sign on the ABiH's coat of arms but also that of the SDA's, whereupon it lost its supra-ethnic meaning. Therefore we can assume that by drawing a fleur-de-lis on the bust in green, the colour of Islam, the depicted Partisan is marked as a hero of the Bosniak nation, rather than as belonging to the Bosnian nation, i.e., of all Bosnians and Herzegovinians including the three constituent peoples plus others. This symbolismeven if the Bosniak participants are unaware of it-is clearly visible to those who do not identify themselves as Bosniaks (here the territory- or identity-marking works in the same way as the new street names in West Mostar; see Palmberger 2013b).

During socialist times, Partisan commemorations were a fixed part of the annual events calendar and were held several times a year, some statewide, some only in certain republics or towns. The main purpose of these commemorations was to strengthen a united Yugoslav identity for which the Partisan myth was crucial (see Chap. 2). Today only a small number of such commemorations is still carried out. The Partisan commemoration with which we are concerned here continued to take place, even in the post-socialist period, every year on 14 February, the day of Mostar's liberation from the Nazis in 1945. This change in context is important to consider when analysing the commemoration because as Olick rightly states: 'The past includes not only the history being commemorated but also the accumulated succession of commemorations, as well as what has occurred between those powerful moments (Olick 2007: 58).

Although nowadays 14 February is a day like any other for most Mostarians, members of the generations educated during Tito's period of rule are still familiar with its former meaning. Present-day Mostarians in their teenage years or early 20s often associate 14 February only with Valentine's Day. An age difference of only a few years can be significant here. The education of those born in the 1970s was still concentrated on the anti-fascist fight and important dates related to it were learned by heart and are surprisingly well remembered even today. On the other hand, those born in the 1980s (especially in the late 1980s) experienced radical educational change (see Chap. 3). It seems, however, that initia-

\footnotetext{
${ }^{11}$ The golden fleur-de-lis became ABiH's highest order of distinction.
} 
tives are being undertaken to revitalise 14 February as a day of commemoration on the Bosniak side. For example, one of the young lecturers at the Bosniak-dominated university told me that she had scheduled the final exams for 14 February. I first assumed this was unintentional, but she told me that she did it on purpose because 14 February was an important day in Mostar's history and students should not forget about it. The question remains as to why the lecturer finds it important to revitalise knowledge about 14 February. Is it only because of the crimes committed in Mostar during WWII, or is the awareness being raised first and foremost because it supports the Bosniak claim of victimisation followed by present-day political and academic elites? This discourse of victimisation is coupled with the Bosniak claim to have acted as the liberators of Mostar from fascism twice in history.

14 February is not a day of celebration in Croat-dominated West Mostar, where 14 February 1945 is remembered first and foremost as the day on which 12 Franciscans were executed. The execution took place at a monastery in Šroki Brijeg, a village close to Mostar, where a bitter battle had been fought between Ustashe and German forces on the one side and Partisan brigades on the other. According to Perica (2002: 110), the Partisans, after great casualties on their own side, captured the stronghold and executed 12 clerics.

The conflict between Bosniak and Croat historiographies today is not about historical facts but primarily about their interpretation. While in the Bosniak historiography the execution of the clerics is marginalised or even silenced as the clerics are viewed as collaborators with the fascists, the execution is central to local Croat historiography because the Franciscans are seen as legitimate supporters of the Croats' struggle for an independent state. This interpretation has also found expression in the new street names in West Mostar. Since the official Croat commemoration of 14 February 1945 is not a day of celebration but of mourning, the former street Avenija 14. Februar (Avenue of 14 February) was renamed Avenija Kralja Tomislava). ${ }^{12}$ In Bosniak-dominated Sarajevo, on the other hand, the street in memory of this Croat ruler of the Middle Ages was renamed. Additionally to renaming Avenija 14 Februar and in order to remember the execution of several clerics by the Partisan, for each of

\footnotetext{
${ }^{12}$ See Slobodna Dalmacija, 24 February 1995.
} 
the clerics a street has been renamed. With this commemorative street naming, elites attempt to 'introduce an authorized version of history into ordinary settings of everyday life' (Azaryahu 1996: 312). But, as argued elsewhere (Palmberger 2017), even if the renaming of streets is a manifestation of the dominant public history discourses, perceptions and representations of the past are more manifold and overlapping than depicted in the topography of street names.

Returning to the linking of the $\mathrm{ABiH}$ with the Partisans as in the commemoration described above, this linking of two histories is not easily accepted by all, even if they have a favourable view of Tito and the Partisans. This became evident in an interview with Miloš, a 40-year-old man who grew up in a Yugoslav family with a Partisan history. Since his parents are Orthodox, the members of his family today are identified as 'Serbs' although they still refer to themselves as 'Yugoslavs'. Before the war Miloš lived in West Mostar with his family, but when the war broke out he and his sister were evacuated by a JNA helicopter. His parents were allowed to stay on the west side only because they had agreed to cooperate, his mother serving as a nurse and his father fighting for HVO. They only did so because they were forced to, Miloš reassured me. When I told him that I participated at the Partisan commemoration (the first one I joined, in 2006) just a few days ago and had been surprised by the large number of commemorators, he gave me his view of the event:

The only objection I have is that I would really like to keep it separate from this conflict that we had now. That's something else and that was the fight of all the peoples and all the nations against the common enemy, against collaborators that we had before, as that we had now. But the thing is, you cannot compare anybody's fight in this war to the Partisan movement because here even though some people prefer to believe differently, it was clear that you had three ethnic armies. There was the Croat HVO, the Serbian Army of Republic Srpska and the so-called Army of BiH; I like to say 'so-called', because $90 \%$ of it or more were Muslims. In their rows they had Mudzahedin, holy warriors from eastern countries, Arabs, coming to fight here, internationally known terrorists, war criminals. People that celebrate February 14 in Mostar put flowers on monuments for Muslim fighters and then go to the Partisan cemetery. How could you? Don't do that 
because it's wrong! History will show what you were fighting for and who was fighting for what. ${ }^{13}$

We gain a better understanding of Milošs resentment of comparing Tito's Partisans with the $\mathrm{ABiH}$ when looking at the historical development of the structure of Bosnia's Partisans and the ABiH (Hoare 2004). The Partisans formed a guerrilla movement and were locally organised. Only towards the end of WWII did the federal Partisan army become organised into a centralised army, the JNA. But with Tito's break with Stalin, the potential need for guerrilla defence was high again. This led the communists to organise a system of territorial defence for which the local population could be mobilised at any point. When socialist Yugoslavia dissolved these territorial defence units, they fell into the hands of the different nationalist parties (the Serb SDS, the Bosniak SDA and the Croat HDZ), depending on which party held the respective territory. The territorial defence units controlled by the SDA, together with the Patriotic League (a Bosniak paramilitary force), eventually formed the Bosnian Army ABiH. At its founding on 15 April 1992, ABiH was-although dominated by Bosniaks - still a multinational army, but at the end of 1993 it became:

the party political army of the SDA, in much the same way as during World War II the Partisans had been the party-political army of the Communist Party. Just as the Communists had indoctrinated the Bosnian Partisans with the ideology of Brotherhood and Unity of Serbs, Croats and Muslims, now the SDA indoctrinated the Bosnian Army with the opposite ideology-the ideology of Bosniak-Muslim nationalism. (Hoare 2004: n.p.)

Viewed from the angle of historical analysis by Hoare (see also Žanić 2007: 488), who outlines the different ideological orientations of the $\mathrm{ABiH}$ and the Partisans, it is curious to see how today the fallen of the $\mathrm{ABiH}$ and of the Partisans is now commemorated within the same ceremony.

\footnotetext{
${ }^{13}$ Unlike most of the other interviews cited in the book which were conducted in the local language, the interview with Miloš was conducted in English so the quotes are from the original interview transcription.
} 


\section{Interpretative Templates for Personal Meaning-Making and as Political Tools}

As has become clear from the First Yugoslavs' narratives, the 1992-1995 war is not as central for this generation as it is for the Last Yugoslavs. WWII and the early years of Yugoslavia experienced during youth and early adulthood have a formative potential and serve as interpretative templates for experiences later in life (see Schuman and Scott 1989). Looking at the data presented in this and in the previous chapter, reflecting on the individual as well as collective levels, we can clearly see how the two wars are linked both in the discursive tactics of the First Yugoslavs and in the discursive strategies employed in the dominant Bosniak public discourse. Despite this conformity, the agendas of the different groups of actors may differ greatly.

In the present post-war public remembrance, remembering the Partisans - the constitutive heroes of Tito's Yugoslavia-has taken on a new meaning. The analysis of the ceremony has shown how the Partisan victims, the liberators who fought against fascism and for a free Yugoslavia, are commemorated today equates them with those who fought against HVO from 1993 until 1994 - also liberators, in the minds of the participants in the ceremony. Not only are the respective liberators subsumed, but so are the respective sets of enemies: the Ustasha and the Croat Defence Council (HVO) are both referred to as the 'fascists'.

Even if several times the organiser and the key protagonists in the ceremony_all First Yugoslavs_-expressed their wish for a shared $\mathrm{BiH}$ and peaceful coexistence among all nations (which is also expressed by ending the ceremony in the alternative youth centre Abraševic) , the ceremony is losing its multinational character. By linking the Partisan liberation fight with that fought by the $\mathrm{ABiH}$, the commemoration has gradually become a Bosniak ceremony. At the same time, it is also acquiring new political relevance and legitimacy.

The analysis of the commemoration held on 14 February also gives insight into the way experiences and their interpretations are communicated by the senior to the junior parts of the population within a commemorative context. While it is common that commemorations are organised by the generation for whom the commemorated event has 
the greatest personal reference, it is central that younger generations are included in the 'community of memory' (Misztal 2003); they can then take over the commemoration even if the witnesses have passed away. In the particular case of the Partisan commemoration this is facilitated by its new political relevance. Although the commemoration is still officially held in memory of the ideals of Brotherhood and Unity, it similarly strengthens a Bosniak national identity.

As pointed out in the Introduction to this book, there is a difference in the nature of the 'stratagems' found in the official national narratives and those in personal narratives. While the former present a goal-oriented narrative, the latter can be better described as target-seeking. While the linking of the two chronotopes (Bakhtin 1981), of WWII and of the 1992-1995 war, among the First Yugoslavs introduced in this chapter, is based first and foremost on personal experiences and aimed at a coherent life narrative (see Cave and Sloan 2014), in a public commemorative context, this linking easily becomes a political tool. As Dragojevic has shown, personal war memories can be exploited when political actors 'may intentionally use symbols or discourse that will sound familiar to those individuals who had personal or family memories of the previous cycles of violence' (Dragojevic 2013). This shows the importance of including both the way interpretative templates serve individual meaning making and, at the same time and connected to the former, how they serve as political tools. Interpretative templates are not only powerful tools for collectively representing and politically 'selling' history but are equally important in the process of understanding and giving meaning to the past on an individual level. Thus they appear in discursive strategies as well as discursive tactics.

Wertsch (2008) differentiates between 'specific' and 'schematic' narrative templates when analysing collective memory in post-Soviet Russia. While the former contain specific information about places, dates and actors, the latter are more abstract and may serve as templates for a variety of narratives. The interpretative templates as understood here are closer to Wertsch's schematic narrative templates but with a stronger emphasis on the aspect of sense making these templates offer to individuals.

On an individual level, First Yugoslavs make use of pre-existing interpretative templates around their experiences of WWII and the early years of Yugoslavia to give meaning to the recent past. The suffering experienced during the 1992-1995 war is brought into immediate relation 
to the suffering experienced during WWII. Moreover, the recent war is narrated in terms of clear categories: fascist perpetrators and victims of fascism, a template borrowed from earlier Yugoslav representations of WWII. This shows the entanglement between personal/individual and public/collective representations of the past, between discursive tactics and discursive strategies transcending different temporalities.

\section{Bibliography}

Azaryahu, Maoz. 1996. The Power of Commemorative Street Names. Environment and Planning 14(3): 311-330.

Bakhtin, Michael. 1981. The Dialogic Imagination: Four Essays. Austin: University of Texas Press.

Bougarel, Xavier. 2007. Death and the Nationalist: Martyrdom, War Memory and Veteran Identity among Bosnian Muslims. In The New Bosnian Mosaic: Identities, Memories and Moral Claims in a Post-War Society, eds. X. Bougarel, E. Helms, and G. Duijzings, 167-192. Aldershot: Ashgate.

Cave, Mark, and Stephen Sloan. 2014. Listening on the Edge: Oral History in the Aftermath of Crisis. Oxford: Oxford University Press.

Dragojevic, Mila. 2013. Memory and Identity: Inter-Generational Narratives of Violence among Refugees in Serbia. Nationalities Papers 41(6): 1065-1082.

Halder, Marc. 2013. Der Titokult: Charismatische Herrschaft Im sozialistischen Jugoslawien. Südosteuropäische Arbeiten, eds. U. Brunnbauer and K. Clewig, 1-10. Munich: Oldenbourg Verlag München.

Helms, Elissa. 2008. East and West Kiss: Gender, Orientalism, and Balkanism in Muslim-Majority Bosnia-Herzegovina. Slavic Review 67(1): 88-119.

Hoare, Marko A. 2004. The Birth and Rise of the Bosnian Army. In Bosnia Report No. 41, ed. Q. Hoare. London: Bosnian Institute. http://www.bosnia.org.uk/ bosrep/report_format.cfm?articleid=1125\&reportid=165 [20.06.2010].

Jansen, Stef. 2005. Who's Afraid of White Socks? Towards a Critical Understanding of Post-Yugoslav Urban Self-Perceptions. Ethnologia Balkanica 9: 151-167.

- 2009. After the Red Passport: Towards an Anthropology of the Everyday Geopolitics of Entrapment in the EU's Immediate Outside. The Journal of the Royal Anthropological Institute 15: 815-832.

Kolstø, Pål. 2006. National Symbolism as Signs of Unity and Division. Ethnic and Racial Studies 29(4): 676-701. 
Leutloff-Grandits, Carolin. 2006. Claiming Ownership in Post-War Croatia: The Dynamics of Property Relations and Ethnic Conflict in the Knin Region. Münster: LIT.

Maček, Ivana. 2009. Sarajevo under Siege: Anthropology in Wartime, The Ethnography of Political Violence. Philadelphia: University of Pennsylvania Press.

Misztal, Barbara A. 2003. Theories of Social Remembering, Theorizing Society. Maidenhead: Open University Press.

Mutevelić, Ico. 1980. Partizanski Spomenik u Mostaru. Ljubljana: ČGP.

Njavro, Mato. 1985. Herzegowina. Zagreb: Privredni vjesnik.

Olick, Jeffrey. 2007. The Politics of Regret: On Collective Memory and Historical Responsibility. New York, NY; London: Routledge.

Palmberger, Monika. 2008. Nostalgia Matters: Nostalgia for Yugoslavia as Potential Vision for a Better Future? Sociologija. Casopis za sociologiju, Socijalnu Psihologiju i Socijalnu Antropologiju 50(4): 355-370.

- 2013. Acts of Border Crossing in Post-War Bosnia and Herzegovina: The Case of Mostar. Identities: Global Studies in Culture and Power 20(5): 544-560.

- 2017. Nationalizing the Streetscape. The Case of Street Renaming in Mostar, Bosnia-Herzegovina. In The Political Life of Urban Streetscapes: Naming, Politics, and Place, eds. R. Rose-Redwood, D. Alderman, and M. Azaryahu. Farnham: Ashgate.

Perica, Vjekoslav. 2002. Balkan Idols: Religion and Nationalism in Yugoslav States. Oxford: Oxford University Press.

Schuman, Howard, and Jacqueline Scott. 1989. Generations and Collective Memories. American Sociological Review 54(3): 359-381.

Stefansson, Anders. 2007. Urban Exile: Locals, Newcomers and the Cultural Transformation of Sarajevo. In The New Bosnian Mosaic: Identities, Memories and Moral Claims in a Post-War Society, eds. X. Bougarel, E. Helms, and G. Duijzings, 59-78. Aldershot: Ashgate.

Van Dijck, Jose. 2006. Record on Hold: Popular Music between Personal and Collective Memory. Critical Studies in Media Communication 23(5): 357-374.

Wertsch, James. 2008. The Narrative Organization of Collective Memory. Ethos 36(1): 120-135.

Žanić, Ivo. 2007. Flag on the Mountain: A Political Anthropology of War in Croatia and Bosnia-Herzegovina, 1990-1995. London and Berkeley, CA: Saqi. 
Open Access This chapter is distributed under the terms of the Creative Commons Attribution 4.0 International License (http://creativecommons.org/licenses/by/4.0/), which permits use, duplication, adaptation, distribution, and reproduction in any medium or format, as long as you give appropriate credit to the original author(s) and the source, a link is provided to the Creative Commons license, and any changes made are indicated.

The images or other third party material in this chapter are included in the work's Creative Commons license, unless indicated otherwise in the credit line; if such material is not included in the work's Creative Commons license and the respective action is not permitted by statutory regulation, users will need to obtain permission from the license holder to duplicate, adapt or reproduce the material. 